\section{RSP}

http://www.rsp.fsp.usp.br/
Revista de Saúde Pública

\title{
Use of generic medicines by the Brazilian population: an evaluation of PNAUM 2014
}

\author{
Andréa Dâmaso Bertoldi', Paulo Sergio Dourado Arrais", Noemia Urruth Leão Tavares"', Luiz \\ Roberto Ramos ${ }^{\mathrm{IV}}$, Vera Lucia Luizav, Sotero Serrate Mengue ${ }^{\mathrm{VI}}$, Tatiane da Silva Dal-Pizzol ${ }^{\mathrm{VII}}$, Mareni \\ Rocha Farias $^{\mathrm{VIII}}$, Maria Auxiliadora Oliveira ${ }^{\mathrm{V}}$
}

I Departamento de Medicina Social. Faculdade de Medicina. Universidade Federal de Pelotas. Pelotas, RS, Brasil

" Departamento de Farmácia. Faculdade de Farmácia, Odontologia e Enfermagem. Universidade Federal do Ceará. Fortaleza, CE, Brasil

III Departamento de Farmácia. Faculdade de Ciências da Saúde. Universidade de Brasília. Brasília, DF, Brasil

Iv Departamento de Medicina Preventiva. Escola Paulista de Medicina. Universidade Federal de São Paulo. São Paulo, SP, Brasil

$\checkmark$ Departamento de Política de Medicamentos e Assistência Farmacêutica. Escola Nacional de Saúde Pública Sérgio Arouca. Fundação Oswaldo Cruz. Rio de Janeiro, RJ, Brasil

vı Programa de Pós-Graduação em Epidemiologia. Faculdade de Medicina. Universidade Federal do Rio Grande do Sul. Porto Alegre, RS, Brasil

VII Departamento de Produção e Controle de Medicamentos. Faculdade de Farmácia. Universidade Federal do Rio Grande do Sul. Porto Alegre, RS, Brasil

VIII Departamento de Ciências Farmacêuticas. Centro de Ciências da Saúde. Universidade Federal de Santa Catarina. Florianópolis, SC, Brasil

\section{ABSTRACT}

OBJECTIVE: To analyze the existence of differences in the use of generic medicines in Brazil according to demographic and socioeconomic variables and acquisition sources of the medicines.

METHODS: Population-based cross-sectional study, conducted with data from the Pesquisa Nacional de Acesso, Utilização e Promoção do Uso Racional de Medicamentos (PNAUM - National Survey on Access, Use and Promotion of Rational Use of Medicines). Data collection took place between September, 2013 and February, 2014 in homes of Brazilian cities (urban area). The use of medicines has been investigated in relation to the treatment of chronic diseases and, in the case of acute events, regarding use over the previous 15 days. Generics were identified by visualization of packaging presented by the users of the medicines. The independent variables used were sex, age, education level, economic class, and region of the Country. The statistical significance of differences between the groups was evaluated by Pearson's Chi-squared test, considering a 5\% significance level.

Received: 15 Jan 2015

Approved: 25 Feb 2016

How to cite: Bertoldi AD, Arrais PSD, Tavares NUL, Ramos LR, Luiza VL, Mengue SS, et al. Use of generic medicines by the Brazilian population: an evaluation of PNAUM 2014. Rev Saude Publica. 2016;50(suppl 2):11s.

Copyright: This is an open-access article distributed under the terms of the Creative Commons Attribution License, which permits unrestricted use, distribution, and reproduction in any medium, provided that the original author and source are credited.

RESULTS: The prevalence of generic medicines use was $45.5 \%$ (95\%CI 43.7-47.3). There was no difference considering education level. The prevalence was higher in females $(47.0 \%$; $95 \% \mathrm{CI}$ 44.9-49.0) than in males (43.1\%; 95\%CI 40.5-45.8), and were higher with increasing age. Generic medicines were more used in the economic class C (47.0\%; 95\%CI 44.9-49.1) and in the South (50.6\%; 95\%CI 46.6-54.6) and Southeast (49.9\%; 95\%CI 46.8-53.0) regions. Generics accounted for $37.3 \%$ of the medicines provided by the Brazilian Unified Health System.

CONCLUSIONS: Currently, there is a choice of purchase or free provision by the Brazilian Unified Health System, characterized by quality assurance and reduced price regarding branded medicines considered as reference. In the private market, a considerable part of the population is choosing generic medicines thanks to the availability of this option for virtually all medicines most used by the population.

DESCRIPTORS: Drugs, generic. Drug Utilization. Socioeconomic Factors. Health Surveys. 
a Brasil. Artigo $6^{\circ}$, de 5 de outubro de 1988. São direitos sociais a educação, a saúde, a alimentação, o trabalho, a moradia, o transporte, o lazer, a segurança, a previdência social, a proteção à maternidade e à infância, a assistência aos desamparados, na forma desta Constituição. In: Brasil. Constituição (1988). Brasília (DF): Senado; 1988.

${ }^{b}$ Brasil. Decreto ${ }^{\circ} 793$, de 5 de abril de 1993. Altera os Decretos $\mathrm{n}^{\circ} \mathrm{S} 74.170$, de 10 de junho de 1974 e 79.094 , de 5 de janeiro de 1977, que regulamentam, respectivamente, as Leis $\mathrm{n}^{\circ} \mathrm{S}$ 5.991, de 17 de janeiro de 1973, e 6.360 , de 23 de setembro de 1976, e dá outras providências. Diario Oficial Uniao. 6 abr 1993.

cMinistério da Saúde. Portaria ${ }^{\circ}$ 3.916, 30 de outubro de 1988. Aprova a Política Nacional de Medicamentos. Diario Oficial Uniao. 10 nov 1988;Seção 1:18-22.

${ }^{d}$ Brasil. Lei n ${ }^{\circ}$ 9.787, de 10 de fevereiro de 1999. Altera a Lei no 6.360 , de 23 de setembro de 1976, que dispõe sobre a vigilância sanitária, estabelece o medicamento genérico, dispõe sobre a utilização de nomes genéricos em produtos farmacêuticos e dá outras providências. Diario Oficial Uniao. 11 fev 1999.

e Brasil. Decreto n 3.961 , de 10 de outubro de 2001. Altera o Decreto no 79.094, de 5 de janeiro de 1977, que regulamenta a Lei $\mathrm{n}^{\circ} 6.360$ de 23 de setembro de 1976 . Diario Oficial Uniao. 11 out 2001;Seção 1:15.

${ }^{\mathrm{f}}$ Associação Brasileira das Indústrias de Medicamentos Genéricos. Pro-genéricos. São Paulo (SP): Associação Brasileira das Indústrias de Medicamentos Genéricos; 2014 [cited 29 Nov 2015]. Available from: http:// www.progenericos.org.br/

\section{INTRODUCTION}

The debate on the policy formulation of generic medicines in Brazil has emerged in the early 1990s, during the process of implementation of the Brazilian Unified Health System (SUS). Being a public health system that aims to ensure integral, universal, and free access to health-care for the entire population of the Country, it included, among its activities, the provision of integral therapeutic assistance ${ }^{a}$. In 1993, in the context of health policies in the pharmaceutical area of the Brazilian Ministry of Health (MS) and as a strategy to reduce prices, the Decree $793^{\mathrm{b}}$ was published, presenting advances such as the highlight to generic names on packs; prescription by the generic name; mandatory presence of the pharmacist in the pharmacy; and permission to fraction the packaging.

In 1998, the National Drug Policy (PNM) was released ${ }^{c}$. In addition to establishing guidelines such as the organization of the health surveillance activities and the reorientation of pharmaceutical services, the PNM had among its objectives to promote the use of generic medicines. In 1999, the National Agency of Sanitary Vigilance (ANVISA) (www.anvisa.gov.br) was created, and the Generic Medicines Policy (Law 9,787/99) was instituted .

Until then, the Brazilian pharmaceutical market was composed by two categories of medicines: the "innovators", today known as reference medicines, which, in addition to their own brand, are registered upon proof of efficacy and safety; and the "similar" drugs, containing the same active ingredients, the same concentration, dosage form, route of administration, dosage, and therapeutic indication of the reference medicine product registered at ANVISA ${ }^{\mathrm{e}}$.

From 1999 on, a new category, the generic medicines, entered the national pharmaceutical market. These medicines, in addition to presenting the characteristics of the similar drugs, must prove that they are interchangeable with the reference medicines registered at ANVISA. Therefore, they must present tests that show pharmaceutical equivalence, and, if necessary, bioequivalence (or relative bioavailability) regarding the reference product ${ }^{16}$.

The implementation of the generic policy fulfilled its initial objectives of encouraging commercial competition, improving the quality of medicines, and facilitating the access of the population to medicines treatment ${ }^{16}$. Besides, the national industry became strong, with significant increase in the number of national companies ( $90.0 \%$ of the generic-producing industries), and also of international companies installed in the Country, in addition to a increase of supply and variety of products. In May 2014, the participation of generic medicines on the market amounted to $28.0 \%$ of sales.

In 2014, it was already possible to treat most of the more prevalent diseases in the Country with generic medicines, which cost up to $35.0 \%$ less than the reference products, thereby improving the affordability of the general population to medicines ${ }^{\mathrm{f}}$.

In this article, we analyzed the existence of differences in the use of generic medicines in Brazil according to demographic and socioeconomic variables and acquisition sources of the medicines.

\section{METHODS}

The Brazilian Ministry of Health, to better know the range of the public policies related to access and rational use of medicines in Brazil, held, in partnership with Brazilian universities and research institutes, a national household survey, called Pesquisa Nacional sobre Acesso, Utilização e Promoção do Uso Racional de Medicamentos (PNAUM - National Survey on Access, Use and Promotion of Rational Use of Medicines).

The PNAUM, a population-based cross-sectional study, was conducted between September 2013 and February 2014. The interviews were conducted in the households and the data recorded in tablets with a software developed specifically for the application 
of the questionnaires. The population under study was of individuals of all ages living in private permanent homes in the urban area of the Brazilian territory. The sample size estimates considered eight demographic domains (different sex and age groups) that were replicated to every major Brazilian geographical region, resulting in 40 sample domains and sample size of 38,400 interviews. The selection of the sample was made in three stages: city (primary unity), censitary sector, and household, and the selection of individuals within households was based on the expected proportion of each age and sex group to compose the final sample. The sampling process was complex and resulted in representative sample of Brazil and its five geographical regions, stratified by sex and age groups. Details about the sampling and logistics of data collection can be found in the methodological article of PNAUM ${ }^{13}$.

The research instrument consisted of a set of questionnaires, developed by researchers from Brazilian universities (researchers and their institutions, as well as the complete research instruments, can be found at http://www.ufrgs.br/pnaum). The use of medicines was investigated from the information on previous diagnosis and medical indication for use of medicines for the treatment of specific chronic diseases (hypertension, diabetes, heart diseases, high cholesterol, history of stroke, chronic lung diseases, arthritis, arthrosis or rheumatism, depression). In the case of acute events, question were made regarding the use of medicines in the last 15 days for a series of symptoms or acute health problems and for any other health reason, in addition to the specified ones (infection, sleep medicines, to the nerves, to stomach or bowel problems, pain, fever, flu, cold or allergic rhinitis, vitamin, mineral supplement, appetite stimulant, or tonic). A separated questionnaire was developed for contraceptives, because of the characteristics of this group of medicines, which is unrelated to diseases.

During the interview, it was requested that the respondent showed all the "remedies" in use. A remedy could be a compounding or industrialized medicine (sold in pharmacies and prescribed by physicians), as well as teas, homeopathic products, and medicinal plants, for example.

The team was trained to recognize generic medicines by observing their packaging and blisters. It was considered as packing the box of the medicine, pack, envelope, tube, bottle, or other container that provided information about the medicine.

This article analyses were carried out using two databases with different denominators. To estimate the prevalence of use of generic medicines, the database containing data of the people included in the sample was used. The prevalence of use of generic medicines was estimated considering in the numerator those who used at least one generic medicine and in the denominator those who presented at least one packing of the medicines used. The prevalence and $95 \%$ confidence intervals $(95 \% \mathrm{CI})$ were also estimated according to the individual characteristics of the respondent: sex (male; female); age in full years (0-9; 10-19; 20-59; 60 or more); education level in complete years ( $0-8 ; 9-11 ; 12$ or more); economic classification (A/B; C; D; E) according to the Brazilian Economic Classification Criterion developed by the Associação Brasileira de Empresas de Pesquisa (CCEB 2013/ABEP - http:// www.abep.org/); and geographical region of residence (North; Northeast; Southeast; South; Midwest).

The sources for obtaining the generic medicines (pharmacy of SUS - public network, private pharmacy, pharmacy from the Farmácia Popular program [Popular Pharmacy Program], and other sources) and the reason for the use of generics (to treat chronic diseases or for any eventual or acute diseases), in the total sample and by age groups, were analyzed from the database of medicines. We used as denominator all medicines whose packaging were presented to the interviewer in favorable conditions to allow the verification of the characteristics to classify them as generics or not $(n=37,419)$. Specifically to contraceptives, information about being generics were not collected from the characteristics of the packaging presented. Therefore, this group of drugs was not analyzed. 
The analyses were carried out in the statistical package Stata 12.0 (StataCorp LP, College Station, Texas, USA), using the appropriate svy commands for the analysis of complex samples and ensuring the necessary weighting (post-stratification weights to correct the response rate bias). The estimated percentages were weighted to adjust the demographic distribution of the PNAUM sample to the distribution of the Brazilian population.

The medicines were classified according to levels 1 and 2 of the Anatomical Therapeutic Chemical (ATC) classification system ${ }^{20}$. The highest frequencies were analyzed on the level 2 of the ATC classification according to the most frequent occurrences at level 1 and, for each one of them, the proportion of generics was estimated regarding the total medicines reported in the respective groups. Medicines that do not have a generic presentation on the market may be included in this analyses, which is reflected in the percentages of use of this type of medicines.

The statistical significance of differences between the groups was evaluated by Pearson's Chi-squared test, considering a 5\% significance level.

The study was approved by Comissão Nacional de Ética em Pesquisa (CONEP - Brazilian National Commission for Ethics in Research; Opinion 398,131, of September 16, 2013) and all the interviews were conducted after the respondents or their legal guardians (in case of children under 18 or people unable to answer their own questionnaire) read and signed the informed consent form.

\section{RESULTS}

The total study sample included 41,433 individuals with distribution by sex and age compatible with the Brazilian population according to the 2010 Census (percentage weighted by sampling weights). The response rates of households were around $50.0 \%$, including as losses the unvisited households. Individuals' response rates were around $90.0 \%$. The methodological article presents a detailed table of response rates by sex and age groups and by geographic regions ${ }^{13}$.

The prevalence of use of at least one generic medicine, estimated among individuals who presented at least one package of medicines $(n=16,316)$, was of $45.5 \%$ (95\%CI 43.7-47.3). We did not observe any differences by education level. However, the prevalence was greater in females than in males ( $47.0 \%$ versus $43.1 \%$, respectively), and was higher with increasing age, with the group aged 60 years old or more using 1.7 times more generics than the group from zero to nine years old. The economic class $\mathrm{C}$ showed higher prevalence of generic medicines use (47.0\%; 95\%CI 44.9-49.1), as well as individuals residing in the South (50.6\%; 95\%CI 46.6-54.6) and Southeast (49.9\%; 95\%CI 46.8-53.0) regions (Table 1).

Packaging or blisters of 37,419 medicines (63.2\% of the total medicines used) were presented at the time of the interviews, allowing the visualization of the characteristics that differentiate generics from other medicines. Of these, 31.2\% (95\%CI 29.8-32.6) were classified as generics. Regarding the sources for obtaining them, the classes with higher purchasing power (A/B) obtained the generic medicines, mainly, in private pharmacies (46.3\%), while in classes $C$ and $\mathrm{D} / \mathrm{E}$ (less spending power), about $50.0 \%$ of generics were obtained in pharmacies from the public network (SUS) (Figure 1). We also observed (data not shown in the figure) that generics accounted for $37.3 \%$ of the medicines obtained by SUS, $53.7 \%$ of those provided by the Popular Pharmacy Program, 24.2\% in private pharmacies, and 16.6\% from other sources (charity institution or churches, free samples, friends, relatives, or neighbors).

Considering the totality of generics used by the individuals from the sample, $68.8 \%$ were used in the treatment of chronic diseases and $31.2 \%$ in acute or potential health problems. The use of generics to treat acute health problems was similar among the age groups. Regarding the generics used for chronic diseases, in the younger groups (children and adolescents), the proportion of generics was equivalent to the medicines used to treat acute problems. 
Table 1. Prevalence of use of at least one generic medicine according to demographic and socioeconomic characteristics. PNAUM, Brazil, 2014

\begin{tabular}{|c|c|c|c|}
\hline \multirow{2}{*}{ Variable } & \multicolumn{3}{|c|}{ Prevalence of use of generics ${ }^{a}$} \\
\hline & $\%^{b}$ & $95 \% \mathrm{Cl}$ & $\mathbf{p}$ \\
\hline Sex & & & 0.013 \\
\hline Male & 43.1 & $40.5-45.8$ & \\
\hline Female & 47.0 & $44.9-49.0$ & \\
\hline Age (years) & & & $<0.001$ \\
\hline $0-9$ & 33.5 & $29.1-37.8$ & \\
\hline $10-19$ & 33.0 & $26.8-39.2$ & \\
\hline $20-59$ & 43.6 & $41.5-45.7$ & \\
\hline$\geq 60$ & 56.2 & $54.1-58.3$ & \\
\hline Education level ${ }^{\mathrm{c}}$ & & & 0.819 \\
\hline $0-8$ years & 45.5 & $43.4-47.6$ & \\
\hline 9-11 years & 44.4 & $40.4-48.3$ & \\
\hline$\geq 12$ years & 45.9 & $43.1-48.6$ & \\
\hline Economic classification $^{d}$ & & & 0.040 \\
\hline $\mathrm{A} / \mathrm{B}$ & 42.6 & $39.5-45.7$ & \\
\hline $\mathrm{C}$ & 47.0 & $44.9-49.1$ & \\
\hline $\mathrm{D} / \mathrm{E}$ & 44.6 & $41.3-48.0$ & \\
\hline Region & & & $<0.001$ \\
\hline North & 32.7 & $28.5-37.0$ & \\
\hline Northeast & 37.9 & $35.8-40.0$ & \\
\hline Southeast & 49.9 & $46.8-53.0$ & \\
\hline South & 50.6 & $46.6-54.6$ & \\
\hline Midwest & 45.1 & $41.9-48.4$ & \\
\hline Total & 45.5 & $43.7-47.3$ & - \\
\hline
\end{tabular}

${ }^{a}$ Only medicines whose packages were shown in the interview allowed the classification as a generic, which corresponds to $63.2 \%$ of the medicines. The prevalence was calculated among those who presented at least one package of their medicines ( $n=16,316$ people).

${ }^{\mathrm{b}}$ Percentages adjusted by sample weights and post-stratification according to age and sex.

c The education level variable presents 278 missings.

${ }^{d}$ The economic classification variable according to the Brazilian Economic Classification Criterion 2013 of the Associação Brasileira de Empresas de Pesquisa (http://www.abep.org) presents 77 missings.

However, in adults and older adults, the proportions of generics were superior, reaching approximately $40.0 \%$ higher in older people regarding children (Figure 2).

Table 2 presents the most used therapeutic groups and sub-groups in the total sample of the packagings presented. The frequency distribution of these groups is comparable to the sample that includes all medicines (regardless of the presentation of the package) (data not presented). Medicines for the cardiovascular system (35.9\%), nervous system (18.6\%), and alimentary tract and metabolism (16.0\%) were the most used ones. Within these therapeutic groups, generics accounted for $40.1 \%, 35.3 \%$, and $29.5 \%$, respectively, of the medicines used. Regarding therapeutic subgroups, the highest proportions of generics occurred for agents acting on the renin-angiotensin system, psychoanaleptics, and drugs used for diabetes $(49.2 \%, 40.9 \%$, and $41.3 \%$, respectively). In the ATC2 subgroup of vitamins (A11), which represented $12.2 \%$ of the medicines for the alimentary tract and metabolism analyzed, no generic was used, because there was no generic on the market for this type of medicine at the time of the research.

Table 3 lists the medicines, in order of frequency of use, including about $50.0 \%$ of the total sample (first column of the table). The second column indicates the percentage of presentation of packaging for each of these medicines, allowing to visualize how much of the drugs was assessed regarding the proportion of generic indicated in the third column. The largest percentages of 


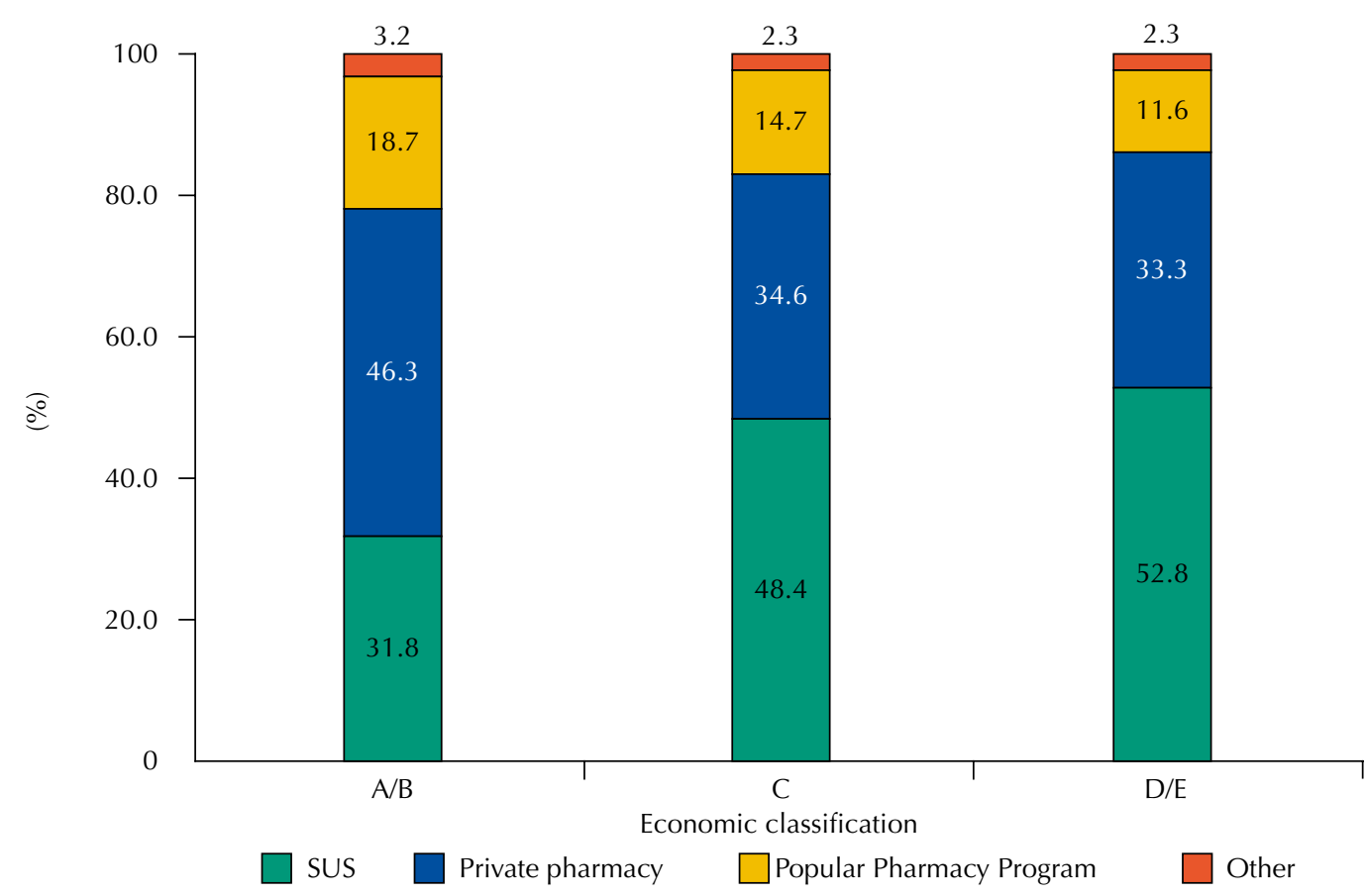

SUS: Brazilian Unified Health System

a Only medicines whose packages were shown in the interview allowed the classification as a generic, which corresponds to $63.2 \%$ of the medicines. Percentages adjusted by sample weights and post-stratification according to age and sex.

${ }^{\mathrm{b}}$ The economic classification variable according to the Brazilian Economic Classification Criterion 2013 of the Associação Brasileira de Empresas de Pesquisa (http://www.abep.org) presents 77 missings.

${ }^{\mathrm{c}}$ Number of medicines classified as generics that have information on economic classification and acquisition source.

Figure 1. Sources for obtaining generic medicines ${ }^{\mathrm{a}}$, stratified by economic classification ${ }^{\mathrm{b}}$ of the users of these medicines. PNAUM, Brazil, 2014. $\left(\mathrm{N}=10,870\right.$ medicines $\left.^{c}\right)$

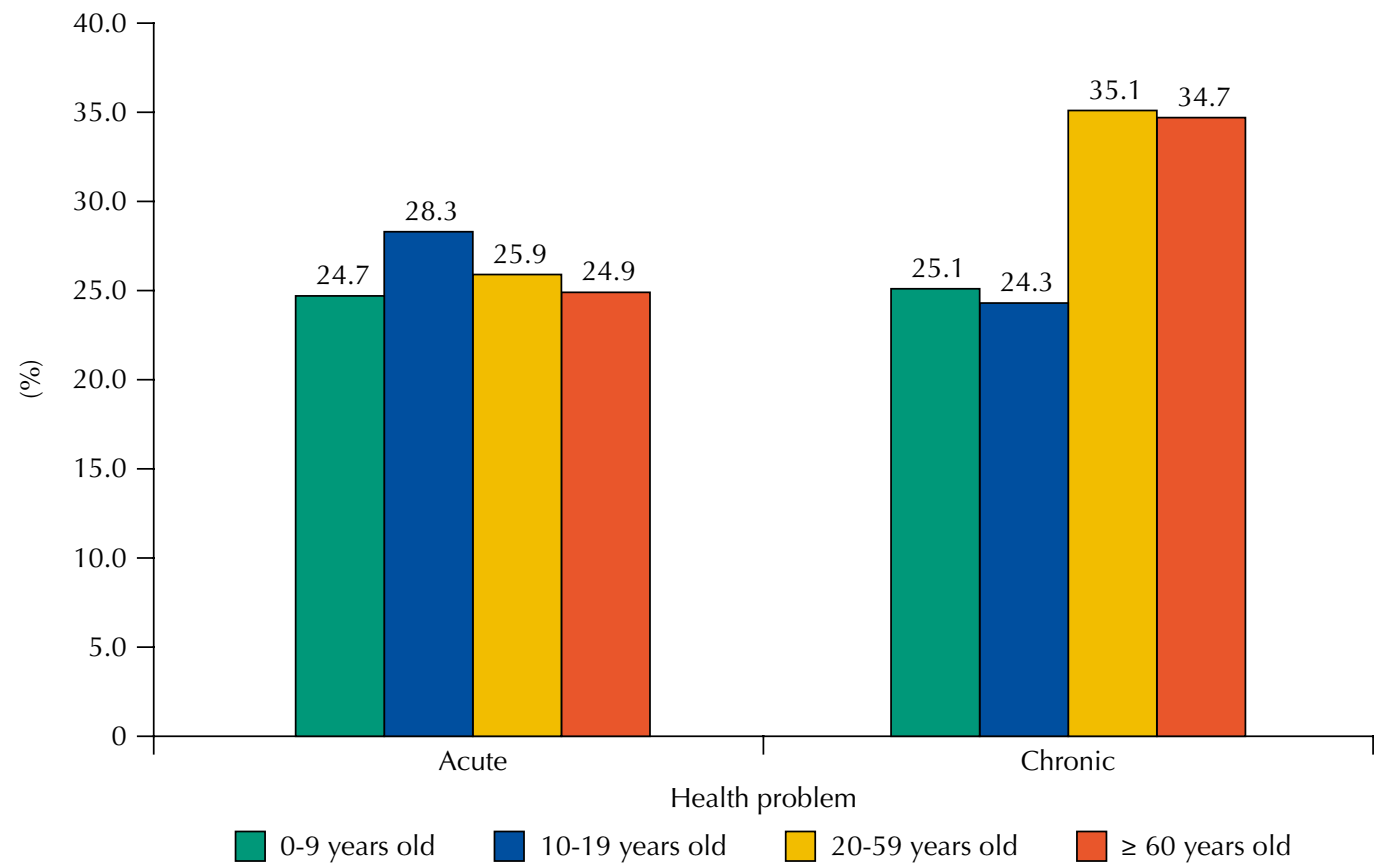

a Only medicines whose packages were shown in the interview allowed the classification as a generic, which corresponds to $63.2 \%$ of the medicines. Percentages adjusted by sample weights and post-stratification according to age and sex.

${ }^{\mathrm{b}}$ Number of medicines classified as generics that have information on age and type of health problem.

Figure 2. Type of health problem treated with generic medicines ${ }^{\mathrm{a}}$ according to the age of the users. PNAUM, Brazil, 2014. $\left(\mathrm{N}=11,215\right.$ medicines $\left.^{b}\right)$ 
Table 2. Therapeutic groups and subgroups most used in the total sample considering only the medicines that had their packages or blisters presented, and proportion of generics in the total of each group. PNAUM, Brazil, 2014. $(\mathrm{N}=37,419)^{\mathrm{a}}$

\begin{tabular}{|c|c|c|}
\hline \multirow{2}{*}{ ATC classification ${ }^{b}$ level 1 and level 2} & \multicolumn{2}{|c|}{ Most used therapeutic groups } \\
\hline & All $(\%)^{c}$ & Generics (\%) \\
\hline C: Cardiovascular system & 35.9 & 40.1 \\
\hline C09 Agents acting on the renin-angiotensin system & 36.9 & 49.2 \\
\hline C03 Diuretics & 22.0 & 37.4 \\
\hline C07 Beta-blockers & 14.1 & 43.0 \\
\hline C10 Lipids modifying agents & 13.4 & 33.9 \\
\hline $\mathrm{N}$ : Nervous system & 18.6 & 35.3 \\
\hline N02 Analgesics & 40.8 & 37.8 \\
\hline N06 Psychoanaleptics & 19.3 & 40.9 \\
\hline N03 Antiepileptics & 17.7 & 27.2 \\
\hline N05 Psycholeptics & 17.3 & 36.7 \\
\hline A: Alimentary tract and metabolism & 16.0 & 29.5 \\
\hline A10 Medicines used for diabetes & 34.2 & 41.3 \\
\hline A02 Medicines for acid-related disorders & 31.6 & 40.7 \\
\hline A11 Vitamins & 12.2 & 0 \\
\hline A03 Medicines for functional gastrointestinal disorders & 9.3 & 18.6 \\
\hline M: Musculoskeletal system & 8.7 & 20.5 \\
\hline M01 Anti-inflammatory and antirheumatic medicines & 63.1 & 25.3 \\
\hline M03 Muscle relaxants & 25.6 & 11.3 \\
\hline M05 Medicines for treatment of bone diseases & 8.4 & 7.3 \\
\hline R: Respiratory system & 5.1 & 18.8 \\
\hline R03 Agents against airway obstructive diseases & 29.9 & 13.4 \\
\hline R06 Antihistamines for systemic use & 29.3 & 30.5 \\
\hline R05 Cough and cold preparations & 21.9 & 23.4 \\
\hline R01 Preparations for nasal use & 18.6 & 3.7 \\
\hline $\mathrm{J}$ : Anti-infectives for systemic use & 2.7 & 37.2 \\
\hline J01 Antibacterials for systemic use & 88.7 & 40.0 \\
\hline J05 Antivirals for systemic use & 6.8 & 20.8 \\
\hline J02 Antifungal agents for systemic use & 2.4 & 3.4 \\
\hline H: Systemic hormonal preparations, excluding sex hormones and insulins & 2.3 & 27.8 \\
\hline H03 Thyroid therapy & 64.0 & 23.2 \\
\hline H02 Corticosteroids for systemic use & 35.8 & 36.4 \\
\hline B: Blood and haematopoietic organs & 2.0 & 15.4 \\
\hline B03 Anti-anemic preparations & 57.5 & 6.3 \\
\hline B01 Antithrombotic agents & 41.6 & 27.9 \\
\hline Other ATC level 1 & 8.6 & - \\
\hline Total ATC level 1 groups & 100 & 31.2 \\
\hline
\end{tabular}

a Only medicines whose packages were shown in the interview allowed the classification as a generic, which corresponds to $63.2 \%$ of the medicines. Contraceptives, despite their packaging, were not classified as generics, therefore, they are not part of this analysis.

${ }^{\mathrm{b}}$ Anatomical Therapeutic Chemical (ATC) classification system. Only the most frequent ATC level 2 are presented for each ATC1 group.

c Percentages adjusted by sample weights and post-stratification according to age and sex.

The values in bold refer to the total from the level 1 of ATC classification.

presentation of packaging (above 80.0\%) were found for medicines used for treatment of chronic diseases, and the lowest (less than 50.0\%), for those used to treat signs, symptoms, or acute affections. The percentages of generics among the most commonly used medicines that could be analyzed ranged from 5.2\% (caffeine + orphenadrine + dipyrone) to $66.4 \%$ (losartan). 
Table 3. List of the most used drugs ${ }^{\mathrm{a}}$ and percentage of use of generics estimated among the medicines that had their packaging presented. PNAUM, Brazil, 2014.

\begin{tabular}{|c|c|c|c|}
\hline \multirow[t]{2}{*}{ Drugs } & $\begin{array}{l}\% \text { of use over the } \\
\text { total number of drugs }\end{array}$ & $\begin{array}{c}\% \text { of packaging } \\
\text { presentation }\end{array}$ & $\begin{array}{c}\% \text { of generics in the } \\
\text { sample }^{b}\end{array}$ \\
\hline & $(n=57,424)$ & $(n=57,424)$ & $(n=37,419)$ \\
\hline Dipyrone & 4.6 & 42.1 & 43.8 \\
\hline Hydrochlorothiazide & 4.1 & 85.1 & 37.9 \\
\hline Paracetamol & 4.0 & 40.9 & 55.4 \\
\hline Losartan & 3.6 & 84.3 & 66.4 \\
\hline Omeprazole & 3.4 & 66.1 & 40.9 \\
\hline Simvastatin & 2.9 & 66.8 & 34.3 \\
\hline Ethinyl estradiol + levonorgestrel ${ }^{\mathrm{c}}$ & 2.7 & 63.2 & - \\
\hline Caffeine + orphenadrine + dipyrone & 2.6 & 33.2 & 5.2 \\
\hline Metformin & 2.5 & 79.2 & 52.3 \\
\hline Captopril & 2.3 & 78.2 & 41.9 \\
\hline Enalapril & 2.3 & 82.2 & 39.5 \\
\hline Atenolol & 1.9 & 77.9 & 53.6 \\
\hline Ibuprofen & 1.6 & 66.4 & 30.0 \\
\hline Acetylsalicylic acid & 1.6 & 72.7 & 17.2 \\
\hline Diclofenac & 1.5 & 63.1 & 27.3 \\
\hline Clonazepam & 1.3 & 81.7 & 39.8 \\
\hline Levothyroxine & 1.3 & 80.3 & 24.1 \\
\hline Amlodipine & 1.2 & 82.4 & 24.3 \\
\hline Amoxicillin & 1.1 & 50.4 & 46.4 \\
\hline $\begin{array}{l}\text { Caffeine }+ \text { carisoprodol }+ \text { diclofenac }+ \\
\text { paracetamol }^{d}\end{array}$ & 1.1 & 59.0 & - \\
\hline Glibenclamide & 1.0 & 83.4 & 34.1 \\
\hline
\end{tabular}

a Corresponding to approximately $50.0 \%$ of all medicines used by the sample.

b Only medicines whose packages were shown in the interview allowed the classification as a generic, which corresponds to $63.2 \%$ of the medicines. Percentages adjusted by sample weights and post-stratification according to age and sex.

c Contraceptives were not classified as generics.

${ }^{\mathrm{d}}$ Drug that does not have a generic version on the market.

\section{DISCUSSION}

The generic medicines policy is part of the $\mathrm{PNM}^{\mathrm{c}}$, since it promotes access by stimulating competition and reduction of prices and spending with medicines. The evaluation of this policy includes studies that analyze the question of prices or that describe the pattern of use of generics. There are many examples of reduction of prices of medicines as a result of the entry of generics in the pharmaceutical market. In this research, the focus of the analyses was to show the use of this type of medicines in the national territory.

Studies indicate, especially at the beginning of the implementation of policies related to generics, some resistance to replace medicines with established brands in the market for generics. However, with time, this scenario has changed because of the benefits arising from lower price, as well as for the guarantee that these medicines are interchangeable with those of reference, by the requirement of proof of pharmaceutical equivalence and bioavailability.

The fact is that, in Brazil, after little more than 10 years from the entry of generics on the market, we have seen that the prevalence of use of this group reached $45.5 \%$ of the population - much higher than the prevalence found in previous researches, which have obtained prevalences of less than $10.0 \%$. Approximately $1 / 3$ of all medicines used were generic, showing the important participation of this group of medicines on the market. Generics are present in over $30.0 \%$ of the pharmacological groups of great demand, such as 
medicines for the cardiovascular system, nervous system, and in some subgroups, such as medicines for diabetes, disturbances related to acidity of the alimentary tract, antihistamines, antibacterials, and corticosteroids of systemic use.

Analyzing the most widely used medicines in the population, it is possible to estimate the participation of generics among the total of medicines used. The most used ones in the generic version were for treating chronic diseases (losartan, metformin, atenolol), but we also observed a medication of high prevalence for acute health problems (paracetamol) and one antimicrobial (amoxicillin). It is important to note the low percentages of generics found for the treatment of bone diseases, airways obstructive diseases, and anti-anemic preparations.

Regarding the characteristics of users of generics, no difference was found regarding education level. Studies of overall use of medicines also found no difference for education level after adjusted analysis. Concerning the differences by sex, invariably, the studies showed higher prevalence of global use of medicines among women. In fact, in general, women use more medicines than men, especially from adolescence on, regardless of the inclusion of contraceptives in the analysis. This suggests that the choice of generic medicines is not related to sex. The higher prevalence of use of generics in females can be a simple reflection of the greater use of medicines in this group.

The use of generics was directly proportional to age, which is consistent with the literature on global use of medicines. Apparently, the preference for using generics occurs between adults and older adults for treatment of chronic diseases. The proportion of generics used for chronic diseases of children and adolescents may be smaller because of the profile of chronic diseases in these age groups, in which it is common for individuals to suffer from, at most, one chronic condition, as opposed to what occurs with adults and, especially, older adults.

Regarding use according to economic classes, the groups of greatest spending power (A/B) presented less frequent use, contrary to what is observed in relation to the use of all medicines in general. Economic classification is directly related to the use of any medicine. However, considering specifically generics, it is possible that groups of greater spending power will choose known brands rather than cheaper options, which, in this case, would be the generic version of these medicines. Classes A/B get their generics, primarily, in private pharmacies, and classes $\mathrm{C}$ and $\mathrm{D} / \mathrm{E}$, primarily in SUS, but this procedure is expected for any type of medicine.

The richest geographic regions (South and Southeast) used more generics than the poorest ones (North and Northeast). For being a cheaper medicine, we expected the opposite. However, similar medicines can be even cheaper than generics, and the option for this type of medicine may have influenced this result. The lack of studies at the time of PNAUM data collection comparing prices of generic medicines with others prevents conclusions on the subject to be more decisive. However, we raised the issue of price as a possibility as well as we should consider the possibility of lower availability of generics in the North and Northeast regions ${ }^{14}$. The Southeast region concentrates most of the generics market in the Country and there is a direct correlation between the number of pharmacies in each Brazilian region and sales of generics. The North and Northeast regions have the lowest proportion of number of pharmacies by population, which may indicate lower offer of this type of medicine.

g Novaretti MCZ, Quitério LM, Piscopo MR. Desafios na gestão de medicamentos genéricos no Brasil: da produção ao mercado consumidor. In: Anais do $38^{\circ}$ Encontro da ANPAD; $13-17$ set 2014 [cited 29 Nov 2015]. Rio de Janeiro (RJ). Available from: http://www.anpad.org.br/ admin/pdf/2014_EnANPAD_

GOL512.pdf
This study presents national and regional representation, which allowed, for the first time, an overview of the use of generic medicines, focus of important government policy aimed at increasing access to medicines. On the other hand, it also presents some limitations, inherent to an investigation of such magnitude. The final response rates included, in addition to the unvisited households, vacant households. This methodological approach may overestimate non-response rates. In addition, there may be some level of commitment of the data arising from the loss of households from the original sample, considering that the lost households, on average, were richer. A detailed discussion of this limitation can be found in the PNAUM methodological article ${ }^{13}$. Since the information depend on the respondents' statements, 
a certain degree of recall error is possible when reporting the medicines used (limitation of the type of data collection, which may lead to an underestimation of the prevalence of use of medicines). Also, because it was not possible to fully obtain the packages of medicines, it was not possible to analyze all drugs used regarding packaging or blisters characteristics, which would enable to identify whether the product used was a generic or not. With this, only $63.0 \%$ of medicines could be classified. However, we observed that the distribution of pharmacological groups and most used drugs was equivalent between medicines whose packaging were submitted and the others. Specifically in the case of contraceptives, for a methodological issue, the use of generics was not analyzed.

With this overview of the generic medicines use in Brazil, we can conclude that today there is a choice of purchase or free provision by the Brazilian Unified Health System, characterized by quality assurance and reduced price regarding medicines of market brands considered as reference. In the private market, much of the population who can exercise their power of choice is choosing this type of medicine, made possible by the existence of a generic option for virtually all the most used medicines by the population.

\section{REFERENCES}

1. Arrais PS, Brito LL, Barreto ML, Coelho HL. Prevalência e fatores determinantes do consumo de medicamentos no Município de Fortaleza, Ceará, Brasil. Cad Saude Publica. 2005;21(6):1737-46. DOI:10.1590/S0102-311X2005000600021

2. Bertoldi AD, Barros AJ, Hallal PC. Generic drugs in Brazil: known by many, used by few. Cad Saude Publica. 2005;21(6):1808-15. DOI:10.1590/S0102-311X2005000600029

3. Bertoldi AD, Barros AJ, Hallal PC, Lima RC. Utilização de medicamentos em adultos: prevalência e determinantes individuais. Rev Saude Publica. 2004;38(2):228-38. DOI:10.1590/S0034-89102004000200012

4. Bertoldi AD, Helfer AP, Camargo AL, Tavares NU, Kanavos P. Is the Brazilian pharmaceutical policy ensuring population access to essential medicines? Global Health. 2012;8:6. DOI:10.1186/1744-8603-8-6

5. Bertoldi AD, Silveira MP, Menezes AM, Assuncao MC, Goncalves H, Hallal PC. Tracking of medicine use and self-medication from infancy to adolescence: 1993 Pelotas (Brazil) birth cohort study. J Adolesc Health. 2012;51(6 Suppl):S11-5. DOI:10.1016/j.jadohealth.2012.06.027

6. Carvalho MF, Pascom AR, Souza-Junior PR, Damacena GN, Szwarcwald CL. Utilization of medicines by the Brazilian population, 2003. Cad Saude Publica. 2005;21 Suppl 1:100-8. DOI:10.1590/S0102-311X2005000700011

7. Costa KS, Barros MB, Francisco PM, Cesar CL, Goldbaum M, Carandina L. Utilização de medicamentos e fatores associados: um estudo de base populacional no Município de Campinas, São Paulo, Brasil. Cad Saude Publica. 2011;27(4):649-58. DOI:10.1590/S0102-311X2011000400004

8. Francisco PM, Bastos TF, Costa KS, Prado MA, Barros MB. The use of medication and associated factors among adults living in Campinas, Sao Paulo, Brazil: differences between men and women. Cienc Saude Colet. 2014;19(12):4909-21. DOI:10.1590/1413-812320141912.18702013

9. Galvao TF, Silva MT, Gross R, Pereira MG. Medication use in adults living in Brasilia, Brazil: a cross-sectional, population-based study. Pharmacoepidemiol Drug Saf. 2014;23(5):507-14. DOI:10.1002/pds.3583

10. Hassali MA, Shafie AA, Jamshed S, Ibrahim MI, Awaisu A. Consumers' views on generic medicines: a review of the literature. Int J Pharm Pract. 2009;17(2):79-88. DOI:10.1211/ijpp.17.02.0002

11. Kobayashi E, Karigome H, Sakurada T, Satoh N, Ueda S. Patients' attitudes towards generic drug substitution in Japan. Health Policy. 2011;99(1):60-5. DOI:10.1016/j.healthpol.2010.07.006

12. Medicins Sans Frontières. Untangling the web of antiretrovira price reductions. 14th ed. Geneva: Medicins Sans Frontières; 2011. 
13. Mengue SS, Bertoldi AD, Boing AC, NUL Tavares, da Silva Dal Pizzol T, Oliveira MA, et al. Pesquisa Nacional sobre Acesso, Utilização e Promoção do Uso Racional de Medicamentos (PNAUM): métodos do inquérito domiciliar. Rev Saude Publica. 2016;50(supl 2):4s. DOI:10.1590/S1518-8787.2016050006156

14. Miranda ES, Santos Pinto CDB, dos Reis ALA, Emmerick ICM, Campos MR, Luiza VL et al. Disponibilidade no setor público e preços no setor privado: um perfil de medicamentos genéricos em diferentes regiões do Brasil. Cad Saude Publica. 2009;25(10):2147-58. DOI:10.1590/S0102-311X2009001000006

15. Olson LM, Wendling BW. The effect of generic drug competition on generic drug prices during the hatch-waxman 180-day exclusivity period. Washington, DC: Bureau of Economics Federal Trade Commission; 2013 (Working paper vol 317).

16. Quental C, de Abreu JC, Bomtempo JV, Gadelha CA. Medicamentos genéricos no Brasil: impactos das políticas públicas sobre a indústria nacional. Cien Saude Colet. 2008;13(Supl):619-28. DOI:10.1590/S1413-81232008000700011

17. Sousa CV, Mesquita JM, Lara JE. Análise da decisão de compra de medicamentos frente à existência de produtos substitutos: um estudo no município de Belo Horizonte, Brasil. Cienc Saude Colet. 2013;18(11):3311-20. DOI:10.1590/S1413-81232013001100021

18. Valente V. Generics in Latin America: an analysis of the Brazilian experience. J Generic Med. 2006;4(1):30-6. DOI:10.1057/palgrave.jgm.4950045

19. Vosgerau MZ, de Souza RK, Soares DA. Utilização de genéricos em área de atuação da equipe de Saúde da Família em município do sul do Brasil. Rev Bras Epidemiol. 2011;14(2):253-63. DOI:10.1590/S1415-790X2011000200007

20. WHO Collaborating Centre for Drug Statistics Methodology. Guidelines for ATC classification and DDD assignment 2014. Oslo: WHO Collaborating Centre for Drug Statistics Methodology; 2013.

Funding: Department of Pharmaceutical Services and Strategic Health Supplies (DAF) and Department of Science and Technology (DECIT) of the Secretariat of Science, Technology and Strategic Inputs of the Ministry of Health (SCTIE/MS - Process 25000.111834/2, Decentralization of Resources from the FNS).

Authors' Contribution: Contributed to the design, analysis, interpretation of results, and critical review of the intellectual content: ADB, PSDA, NULT, and MAO. All authors participated in the writing, approved the final version of the manuscript, and declare to be responsible for all aspects of the study, ensuring its accuracy and completeness.

Acknowledgments: To the Ministry of Health, for the funding and technical support for the implementation of the Pesquisa Nacional sobre Acesso, Utilização e Promoção do Uso Racional de Medicamentos (PNAUM - National Survey on Access, Use and Promotion of the Rational Use of Medicines) and, in particular, to the team that worked on data collection, here represented by professor Dr. Alexandra Crispim Boing; and to the statistical support team of the project, in the names of Amanda Ramalho Silva, Andréia Turmina Fontanella, and Luciano S. P. Guimarães.

Conflict of Interest: The authors declare no conflict of interest. 